\title{
Buprenorphine and pain treatment in pediatric patients: an update
}

This article was published in the following Dove Press journal: Journal of Pain Research

\author{
Erendira Vicencio-Rosas' \\ María Gabriela \\ Pérez-Guillé2 \\ Carmen Flores-Pérez ${ }^{2}$ \\ Janett Flores-Pérez ${ }^{2}$ \\ Francisca Trujillo-Jiménez ${ }^{2}$ \\ Juan Luis Chávez-Pacheco \\ 'Anesthesiology Department, \\ Hospital Regional de Alta Especialidad \\ "Bicentenario de la Independencia", \\ ISSSTE, Tultitlán de Mariano Escobedo, \\ México; ${ }^{2}$ Pharmacology Laboratory, \\ Instituto Nacional de Pediatría, \\ Ciudad de México, México
}

Correspondence: Juan Luis

Chávez-Pacheco

Laboratorio de Farmacología, Instituto Nacional de Pediatría, Av. Imán No I,

Col. Insurgentes Cuicuilco, CP 04530 ,

Ciudad de México, México

Tel $+52 \quad 10840900$ ext I428

$\mathrm{Fax}+52 \quad 10843883$

Email jchavez_pacheco@hotmail.com
Introduction: The usual management of moderate to severe pain is based on the use of opioids. Buprenorphine (BPN) is an opioid with an analgesic potency 50 times greater than that of morphine. It is widely used in various pain models and has demonstrated efficacy and safety in adult patients; however, there are insufficient clinical trials in pediatric populations.

Purpose: The aim of this study was to perform an updated meta-analysis on the implementation of BPN in the treatment of pain in the pediatric population.

Methods: A bibliographic search was carried out in different biomedical databases to identify scientific papers and clinical trials with evidence of BPN use in children and adolescents.

Results: A total of 89 articles were found, of which 66 were selected. Analysis of these items revealed additional sources, and the final review included a total of 112 publications.

Conclusion: Few studies were found regarding the efficacy and safety of BPN use in children. In recent years, the use of this drug in the pediatric population has become widespread, so it is imperative to perform clinical trials and pharmacological and pharmacovigilance studies, which will allow researchers to develop dosage schemes based on the evidence and minimize the risk of adverse effects.

Keywords: buprenorphine, opioid, analgesia, child, adverse effects, pharmacokinetics

\section{Introduction}

Optimal pain treatment requires multimodal strategies based on the identification of the causal mechanisms and intensity to individualize treatment. Pain is defined as "an unpleasant sensory and emotional experience associated with real or potential tissue damage." 1,2

Pain is the most common health symptom during childhood and adolescence. ${ }^{3}$ Although the magnitude of the detrimental effects pain can have on a child is known, it is often inadequately evaluated and treated ${ }^{4,5}$ due to ignorance of the pathophysiological aspects of pain at this stage of life and limited clinical information on the use of certain drugs. ${ }^{6-8}$

Pain can be classified into acute and chronic pain. The former is defined as the expected normal physiological response to adverse chemical, mechanical, or thermal stimuli associated with surgery, trauma, or acute diseases..$^{9}$ Over $80 \%$ of adult patients undergoing surgical procedures experience acute postoperative pain of moderate to severe intensity ( $75 \%$ of cases). ${ }^{10}$ In children, the prevalence of postoperative pain is reported in up to $50 \%$ of cases $^{11}$ of which up to $20 \%$ develop postsurgical chronic pain. ${ }^{12}$ Chronic pain can be caused by a variety of conditions. Chronic pain is the main 
symptom experienced by children with cancer and occurs in at least $89 \%$ of patients in advanced stages of this disease. ${ }^{13,14}$

Analgesic therapy established by the World Health Organization (WHO) aims to keep pediatric patients calm and free of pain and provides pharmacotherapeutic strategies based on their intensity and pathologic condition. ${ }^{15-17}$ The recommendation for the use of analgesics is as follows:

1. non-opioid analgesics (paracetamol and anti-inflammatory drugs);

2. opioids (morphine, methadone, hydromorphone, buprenorphine [BPN], fentanyl and oxycodone);

3. local anesthetics (lidocaine, bupivacaine and ropivacaine); and

4. adjuvant analgesics (anticonvulsants, antidepressants, corticosteroids and ketamine).

Opioids are an important tool for treating moderate to severe persistent pain. Approximately $60 \%-90 \%$ of children in palliative care will receive this type of medication. ${ }^{18}$

BPN is a semisynthetic opioid developed in the $1960 \mathrm{~s}^{19}$ and, although not the first line treatment for pain, has proven to be a good analgesic with prolonged effect. ${ }^{20}$ In the $1980 \mathrm{~s}$, the US Food and Drug Administration authorized intravenous (IV) BPN administration, and subsequently other dosage forms were developed (Figure 1). In the 40 years of BPN use, there has been little information regarding its use and pharmacokinetics (PK) in children, especially in the treatment of chronic pain.

The aim of this study was to conduct an updated metaanalysis on the implementation of BPN in the treatment of pain in the pediatric population.

\section{Methods}

A search was performed on biomedical databases, The Cochrane Database of Systematic Reviews, EMBASE,
MEDLINE (PubMed and Ovid), Scopus, KoreaMed, National Library of Australia, and LILACS, to identify articles concerning the use of BPN in children and adolescents. No time or language restrictions were applied.

The Medical Subject Headings terms used were as follows: BPN, pain, child, neonates, infant, adolescent, analgesia, pharmacokinetics, pharmacodynamics, adverse reaction, transdermal patch, sublingual, intravenous administration, and infusion intravenous.

The search in all databases yielded 89 results, duplicates and articles that after a critical reading were considered not relevant were eliminated, yielding 66 documents. From these sources, additional items were identified. The final review was performed with a total of 112 publications.

\section{Pharmacological properties}

BPN is a semisynthetic opioid derived from thebaine, with an antinociceptive effect 30-50 times more powerful than morphine.${ }^{27}$ In trials, intramuscularly administered BPN has 25 times more potency than intramuscular (IM) morphine and sublingual (SL) administration is 15 times more potent than IM morphine. ${ }^{28}$

BPN's chemical structure is basically that of an opioid with multiple chiral centers. However, a tert-butyl group in carbon position 7 contributes to its lipophilicity. BPN has a low molecular weight $(467.64 \mathrm{~g} / \mathrm{mol})$ and is a base with a $\mathrm{pKa}$ between 8.2 and 10.0 and a melting point of $218^{\circ} \mathrm{C} .^{27,29} \mathrm{BPN}$ 's physicochemical properties favor tissue penetration in both transdermal and transmucosal formulations..$^{29,30}$

BPN is a centrally acting analgesic that binds to opioid receptors $^{19,31}$ to generate inhibition of the transmission of nociceptive impulses from the periphery to the spinal cord and activation of downstream pathways inhibitory modulating pain transmission. In addition, BPN can modify activity in the limbic system (affective and sensory-discriminative components). ${ }^{32-34}$

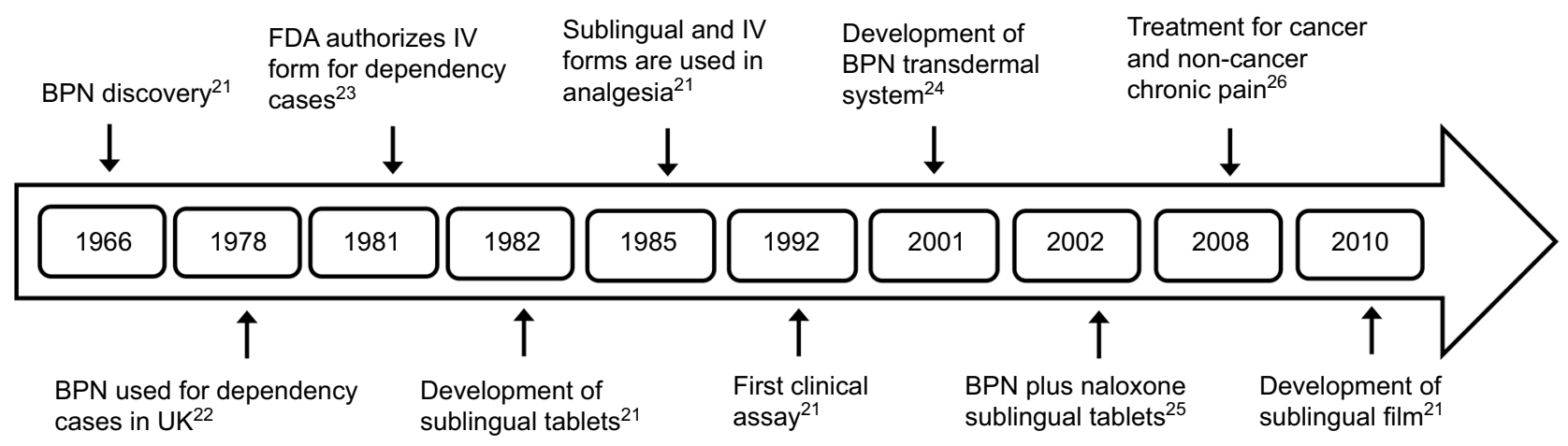

Figure I Timeline of development of pharmaceutical forms and authorized use of BPN. Abbreviations: BPN, buprenorphine; FDA, US Food and Drug Administration; IV, intravenous. 
BPN's pharmacological profile has not been fully resolved, since the union of BPN and the opioid receptor is high but not selective. Differences in the profile have been observed depending on the model (animal, human), conditions (in vitro/in vivo), and experimental model (pain, dependence, or respiratory depression). This finding has resulted in misconceptions that have limited the clinical utility in certain population groups.

\section{Pharmacokinetics}

Drug absorption is dependent on the route of administration and BPN can cross the blood-brain barrier and placenta. Parenteral administration generates brain concentrations 2-3 times greater than those achieved by oral administration. Some studies in rats indicate that BPN is rapidly distributed in the brain after IV administration. Due to its polarity, the metabolite norbuprenorphine rapidly penetrates the central nervous system (CNS) without modification. ${ }^{23}$

BPN has high affinity for globulins type $\alpha$ and $\beta(95 \%-98 \%)$ and poor binding to albumin. ${ }^{35}$ It possesses extensive first pass metabolism in the gut wall and the liver, primarily by cytochromes CYP3A4 and 3A5 (65\%), CYP2C8 (30\%), and with less active CYP2C9, CYP2C18, and CYP2C19. Cytochromes P450 (CYPs) transform BPN via N-dealkylation into norbuprenorphine (active metabolite). CYP3A4 may also catalyze hydroxylation of both compounds to generate hydroxybuprenorphine and hydroxynorbuprenorphine. ${ }^{36}$ Moreover, the uridine diphosphate glucuronosyltransferases (UGT1A1 and UGT2B7) perform glucuronidation to obtain the inactive metabolites BPN-3-glucuronide and norbuprenorphine-3-glucuronide (Figure 2) ${ }^{37}$ It is known that the maximum plasma norbuprenorphine concentrations are equal to or higher than BPN concentrations.

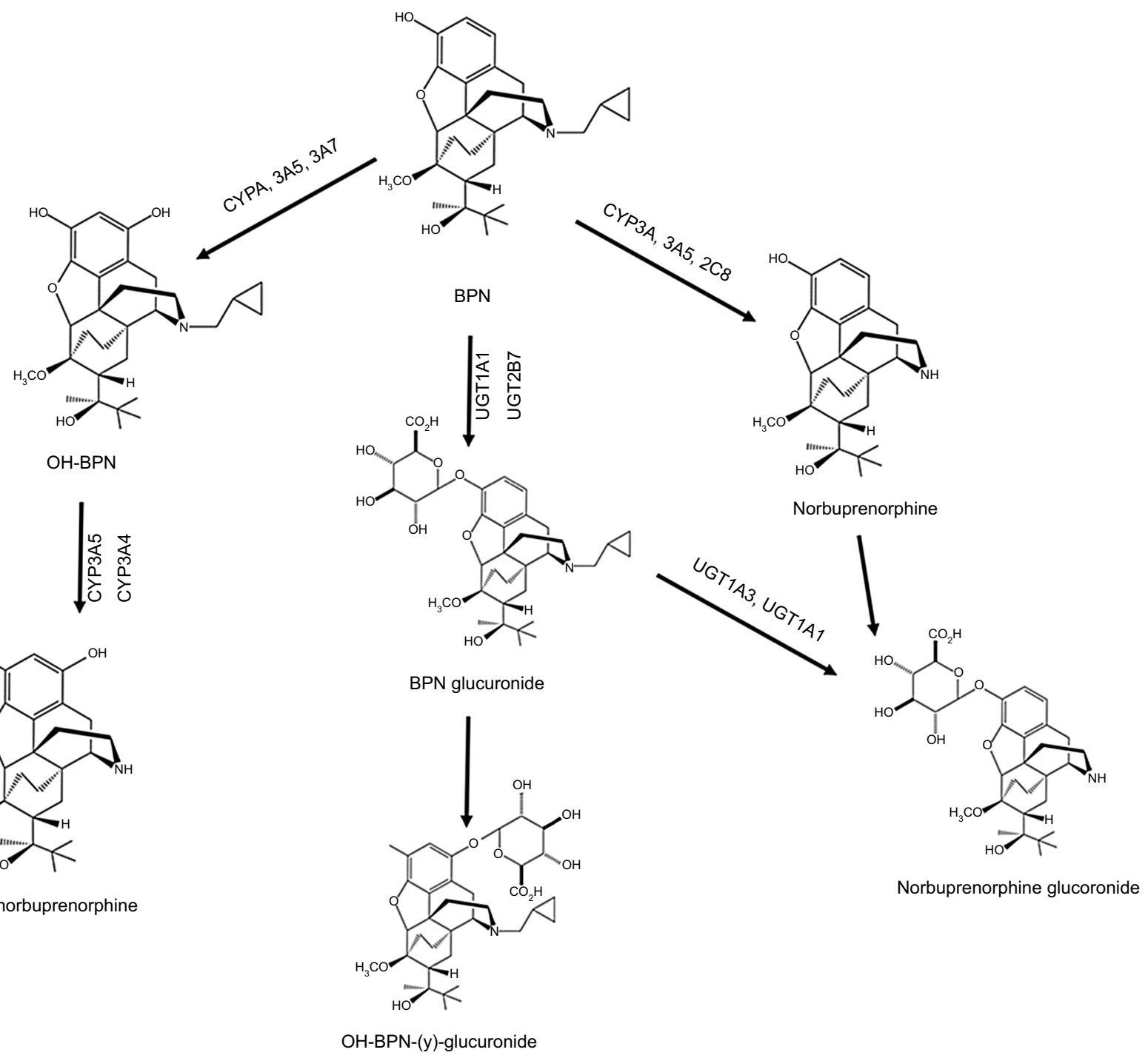

Figure 2 Metabolism of BPN. Cytochromes P450 produce hydroxybuprenorphine, hydroxynorbuprenorphine, and norbuprenorphine. The glucosyltransferases (UGTIA3, UGTIAI) produce BPN glucuronide, hydroxyl BPN glucuronide, and norbuprenorphine glucuronide. Abbreviation: BPN, buprenorphine. 
BPN is excreted in an unaltered or $\mathrm{N}$-dealkylated form in the feces $(50 \%-71 \%)$ and urine $(10 \%-17 \%),{ }^{38}$ which favors its administration in patients with renal failure. This drug can be used in elderly patients because the PK is not affected by age. ${ }^{39,40}$ It is also a safe opioid in patients with mild to moderate liver failure and does not require dosage adjustment. ${ }^{41,42}$ The plasma elimination of BPN follows a multi-exponential curve with a half-life of $\sim 3-5$ hours in postoperative patients. ${ }^{43}$ Its agonist and antagonist properties are related to the dosage and administration route. ${ }^{41,44}$

\section{Pharmacokinetic parameters in adults}

These values are dictated by the administration route as follows.

\section{Intravenous}

Absorption is immediate with $100 \%$ bioavailability. The maximum plasma concentration (Cmax) is reached in $2-5$ minutes. Elimination has a rapid phase half-life $\left(t_{1 / 2} \alpha\right)$ of $2-5$ minutes, followed by a redistribution time $\left(t_{1 / 2} \beta\right)$ of $20-30$ minutes, and a slow phase time $\left(\mathrm{t}_{1 / 2} \delta\right)$ from 2 to 3 hours. ${ }^{27,45}$

\section{Oral}

Absorption is very low due to extensive first pass metabolism, with $10 \%-16 \%$ bioavailability. BPN tablets produce plasma levels of $50 \%$ compared to those achieved with liquid preparations. $^{46}$

\section{Sublingual}

Absorption is rapid, with variable bioavailability of $30 \%-60 \%$ due to protein binding and interindividual variability. Cmax is reached at 2 hours. Plasma concentrations fall rapidly in the first 6 hours, then a gradual decrease is observed for 24 hours. ${ }^{47,48}$ Tmax is variable in healthy volunteers; doses of 0.4 and $0.8 \mathrm{mg}$ (drops) give Tmax values of 30 and 60 minutes, respectively. The same doses in sublingual tablets have Tmax values of 90 and 360 minutes, respectively. ${ }^{23}$

\section{Transdermal}

Distribution is rapid in nerve tissue, with 5\% bioavailability. ${ }^{49}$ The administration in patches containing 20 and $40 \mathrm{mg}$ (release rate of 35 and $70 \mathrm{mg} / \mathrm{h}$ ) shows that the minimum effective concentration $(100 \mathrm{pg} / \mathrm{mL})$ is reached at 21 and 11 hours after patch application, respectively. ${ }^{50}$

In another trial, the administration of a patch containing $20 \mathrm{mg}(35 \mu \mathrm{g} / \mathrm{h})$ achieved a Cmax of $300 \mathrm{pg} / \mathrm{L}$ and Tmax at 60 hours. ${ }^{51}$ The area under the curve was $20.22 \mathrm{pg} / \mathrm{h}$. No differences were observed in PK parameters in patients with renal failure nor were there parameter changes in older adults..$^{39,52,53}$

\section{Intranasal}

The intranasal formulation is fast acting, with $50 \%$ bioavailability and a Tmax of 30 minutes. ${ }^{23}$ Lipophilic drugs such as BPN are generally well absorbed from the nasal mucosa and have PK profiles such as those obtained by IV administration. This formulation is interesting for the treatment of irruptive cancer pain. The intranasal formulation is currently under development and has been used only in animal models and healthy volunteers.

\section{Pharmacokinetic parameters in children}

The PK of this drug has been described using a model of two or three compartments. In children, there is limited information regarding the estimation of PK parameters. The first study used allometric pediatric models to estimate parameters in children older than 2 years using the PK parameters of adult patients. ${ }^{45}$

In a 1989 study, BPN was administered intravenously at a premedication dose of $3 \mu \mathrm{g} / \mathrm{kg}$ among patients undergoing minor surgery (4.6-7.5 years). The PK showed a biexponential behavior (due to enterohepatic recirculation) with two half-lives, a quick half-life at 5 minutes and a slow half-life at 62 minutes. The mean clearance was $60 \mathrm{~mL} / \mathrm{min} /$ $\mathrm{kg}$ and a volume of distribution at steady state was in the range of $1.2-8.3 \mathrm{~L} / \mathrm{kg}$. No correlation was found between the PK parameters and age, weight, or body surface area. ${ }^{54}$ The average clearance is three times higher in children than adults; this is because the liver/body weight ratio is greater in children. The values of the volume of distribution at steady state were similar in both populations. ${ }^{54}$ The author concluded that because the BPN clearance is higher in children than in adults, there are no contraindications for BPN use as an analgesic in children. A comparison of the PK values in adults and children is shown in Table 1.

In contrast, a study in preterm infants (27-32 weeks gestational age) receiving BPN at $0.72 \mu \mathrm{g} / \mathrm{kg} / \mathrm{h}$ by continuous infusion concluded that this administration route does not provide stable sedation or analgesia and, therefore, its use is not recommended. Further, in this population the clearance is reduced due to the immaturity of glucuronidation systems. ${ }^{55}$

\section{Pharmacodynamics}

BPN is a partial mu receptor agonist, partial or complete opioid receptor-like 1 (ORL1) agonist, and kappa and delta receptors antagonist, ${ }^{56-59}$ characterized by a lasting action 
Table I Pharmacokinetic parameters in different pharmaceutical forms

\begin{tabular}{|c|c|c|c|c|c|c|}
\hline \multirow{3}{*}{$\begin{array}{l}\text { Pharmacokinetic } \\
\text { parameters }\end{array}$} & \multicolumn{6}{|c|}{ Pharmaceutical forms } \\
\hline & \multicolumn{2}{|c|}{ Intravenous } & \multicolumn{2}{|l|}{ Sublingual } & \multicolumn{2}{|c|}{ Transdermal } \\
\hline & Adults & Children & Adults & Children & Adults & Children \\
\hline Bioavailability (\%) & 100 & 100 & $30-60^{27,47,48}$ & $30-55^{27}$ & & $50^{49}$ \\
\hline $\mathrm{Cmax}(\mathrm{ng} / \mathrm{mL})$ & $18.1 \pm 3.1^{45}$ & & & & $300^{51}$ & \\
\hline $\operatorname{Tmax}(\min )$ & $2-5^{45}$ & & $30-180^{27,47,48}$ & $90-360^{27}$ & $3600^{51}$ & $660-1260^{50}$ \\
\hline $\mathrm{T}_{1 / 2}(\mathrm{~h})$ & $3.06 \pm 0.6^{45}$ & $1.0 \pm 0.2^{54}$ & & & $25.3^{51}$ & $20 \pm 8^{27}$ \\
\hline $\mathrm{Cl}_{\mathrm{T}}(\mathrm{mL} / \mathrm{min} \mathrm{kg})$ & $18.2 \pm 1.2^{45}$ & $60 \pm 19^{54}$ & $50^{27}$ & & & $0.14^{27}$ \\
\hline Vss (L/kg) & $2.7 \pm 0.5^{45}$ & $3.2 \pm 2^{54}$ & & & & $6.2 \pm 2.1^{27}$ \\
\hline
\end{tabular}

Note: Pharmacokinetic values obtained in clinical studies for adults and children.

Abbreviations: Cmax, maximum plasmatic concentration; Tmax, time to obtain $\mathrm{Cmax}_{\mathrm{T}} \mathrm{T}_{1 / 2}$, half-life for buprenorphine; $\mathrm{Cl}_{\mathrm{T}}$, clearance total; $\mathrm{Vss}_{\mathrm{ss}}$, volume of distribution at steady state.

associated with a slow dissociation from the receptor and low intrinsic activity in in vitro assays..$^{38,60,61}$ These properties allow BPN to displace other mu-agonists and explain its therapeutic effect on opioid dependence. In contrast to the full mu receptor agonists, BPN has a pronounced antihyperalgesic effect ${ }^{36}$ and does not cause internalization of opioid receptors which decreases the possibility of inducing tolerance or dependence. ${ }^{29}$

BPN is a potent opioid in low doses, but at higher doses it has a relative decreased potency, which is a feature of partial opioid agonists. ${ }^{23}$ In adults, BPN has a ceiling effect on respiratory depression but not in analgesia. ${ }^{38,61}$ The dose for the ceiling effect relates to the partial agonist activity of the receptors mu and ORL1. ${ }^{62-65}$ It is thought that the supraspinal component of the antinociception induced by BPN is not mediated by the opioid mu response, but by unique receptors. ${ }^{41}$

BPN's effects on ventilation are controversial. Hovell and Banks have reported that BPN has little effect on adult patients, ${ }^{66,67}$ but other authors report ventilator depression as with morphine. ${ }^{20,68}$ The magnitude of this respiratory effect is variable and independent of the interaction with the mu receptor. ${ }^{69}$

BPN ceiling effect in children is controversial and not well defined..$^{15}$ It is known that the opioid interaction with the mu receptor can depress respiration; this side effect is variable and dependent of different factors such as genetics, age, sex, concomitant medication, and others. ${ }^{69}$ In fact, BPN and its active metabolite norbuprenorphine exhibit a respiratory depressant activity.

In previous studies performed by Dahan et al, they observed a nonlinear dose/response relationship, with a ceiling at above $0.1 \mathrm{mg} / \mathrm{kg}$ doses and a moderate increase of $\mathrm{PaCO}_{2}$, providing lower rates of respiratory depression than other opioids, such as fentanyl ${ }^{70}$ further, they found that BPN's analgesic effect increased significantly using two different doses, while the respiratory depression was similar in magnitude for both doses. They concluded that "over the dose range tested buprenorphine displays ceiling in respiratory effect but none in analgesic effect."”1

The effective analgesic action of BPN is achieved with a relatively low occupancy of receptors $(5 \%-10 \%)$. As a result, the analgesia degree is not closely correlated with plasma concentrations. ${ }^{72}$ Therapeutic concentrations between 100 and $500 \mathrm{pg} / \mathrm{mL}$ are enough to relieve moderate to severe pain.

\section{Pharmaceutical forms and administration}

BPN is marketed in the form of SL tablets, tablets, an injectable solution, a transdermal patch, and an oral film.

The administration routes described for the pediatric population are IV; IM; SL; subcutaneous; and neuraxial (peridural/caudal). Other routes of administration are intraarticular and intranasal; however, there is no clinical evidence of these uses in children. ${ }^{38}$

In recent years, the use of a transdermal patch has been evaluated, although in children its safety and efficacy have not been well established. ${ }^{73}$ Several case reports have proved that the patch is useful in palliative care patients with pain associated with cancer at doses ranging from 7.5 to $52.5 \mu \mathrm{g} / \mathrm{h}^{49,74}$

Böhme notes that chronic pain patients treated with transdermal BPN could reduce the total consumption of SL tablets per day by almost $70 \%$, and $50 \%$ of cases experienced relief of their severe pain. The highlighted advantages of the transdermal patch are the constant supply of active substance, painless administration, and greater comfort for the patient, all of which have a positive impact on the quality of life. ${ }^{75}$

The transdermal system utilizes a matrix technology, and it is available in patches containing $5,10,20,30$, and $40 \mathrm{mg}$ of BPN, with release rates of $5,10,35,52.5$, and $70 \mu \mathrm{g} / \mathrm{h}$, respectively. ${ }^{76}$ The diversity of presentations allows an 
adequate dose to be administered without cutting the patch. This is a promising therapy in the treatment of chronic pain in children. Dosage regimens used to control pain in children are described in Table 2.

\section{Drug interactions}

The main drug interactions can be divided into mild and severe (Table 3 ). BPN interacts with drugs that cause CNS depression, increasing the risk of overdose. ${ }^{23}$ The mechanism of interaction is probably due to additive or synergistic pharmacological effects. Preclinical studies also suggest that benzodiazepines may alter the ceiling effect of respiratory depression induced by BPN. ${ }^{87}$

BPN and its major metabolites cause inhibition of CYP2D6 and CYP3A4; however, this effect is not clinically relevant at therapeutic concentrations with other drugs metabolized by CYP450. Drugs that interfere with CYP3A4, such as erythromycin, ketoconazole, and inhibitors of HIV protease (ritonavir, indinavir, saquinavir) may decrease norbuprenorphine production. ${ }^{76}$

Although $96 \%$ of BPN is bound to plasma proteins, there is no competition with transport proteins in the plasma, as BPN binds primarily to globulins $\alpha / \beta .^{35}$
Coadministration of BPN with other drugs that prolong QT interval may result in additive effects and increase the risk of ventricular arrhythmias and sudden death. Patients with congenital long QT syndrome, conduction abnormalities, or electrolyte abnormalities (eg, loss of magnesium or potassium due to diarrhea or vomiting) are more susceptible to such interactions. ${ }^{83,84}$

When starting BPN administration, it is advisable to prescribe the lowest effective doses and a drug administration at the minimum required, especially in patients receiving another CNS depressant. Close monitoring is also recommended.

\section{Adverse drug reactions}

Opioids definitively improve the quality of life among patients with pain; however, the use of these drugs has been limited by fears about safety and tolerability. Adverse reactions with opioids occur in up to $80 \%$ of cases, mainly affecting the gastrointestinal tract (30\%) and, to a lesser extent, the other organs and systems. ${ }^{97}$

The mild or moderate adverse effects most frequently observed are constipation (25\%), somnolence (23\%), nausea $(21 \%)$, dry mouth (17\%), and symptoms of vomiting,

Table 2 Dosage and administration routes of buprenorphine in the pediatric population

\begin{tabular}{|c|c|c|c|c|}
\hline Dosage form & Route & Indications & Recommended dose & Age (years) \\
\hline Injectable solution & IV & Premedication & $1.5-3 \mu \mathrm{g} / \mathrm{kg}$ & $3-17^{77}$ \\
\hline ( $0.3 \mathrm{mg}$ buprenorphine & & Postoperative analgesia & & $0.5-6^{15}$ \\
\hline \multirow[t]{10}{*}{ hydrochloride) } & & Chronic pain in palliative care & $\mathrm{I}-6 \mu \mathrm{g} / \mathrm{kg}$ & $>0.5^{18}$ \\
\hline & & Chronic pain & & \\
\hline & PCA & Chronic pain in palliative care & $3 \mu g / \mathrm{kg}$ & $>0.5^{18}$ \\
\hline & & Postoperative analgesia & $(\max 150 \mu \mathrm{g}) 6 \mathrm{~h}$ & \\
\hline & $\mathrm{Cl}$ & $\begin{array}{l}\text { Maintenance of mechanical } \\
\text { ventilation }\end{array}$ & $0.72-2.16 \mu \mathrm{g} / \mathrm{kg} / \mathrm{h}$ & $27-32 W G^{55}$ \\
\hline & & Chronic pain in palliative care & $\begin{array}{l}0.5 \mu \mathrm{g} / \mathrm{kg} / \mathrm{h} \\
(\max 30 \mathrm{mg} / \mathrm{h})\end{array}$ & $>0.5^{18}$ \\
\hline & SC & Pain in palliative care & $\begin{array}{l}0.5 \mu \mathrm{g} / \mathrm{kg} / \mathrm{h} \\
(\max 30 \mu \mathrm{g} / \mathrm{h})\end{array}$ & $>0.5^{18}$ \\
\hline & Epidural & Postoperative analgesia & $2.5-4 \mu g / \mathrm{kg}$ & $11.01^{78}$ \\
\hline & & & & $0.5-12^{79}$ \\
\hline & & & & $11-13^{80}$ \\
\hline Sublingual tablets & SL & Premedication & $3 \mu g / \mathrm{kg}$ & $4.8-15^{81}$ \\
\hline ( $0.2 \mathrm{mg}$ buprenorphine & & Chronic pain & & \\
\hline \multirow[t]{2}{*}{ hydrochloride) } & & Postoperative analgesia & & \\
\hline & & Chronic pain in palliative care & $4-200 \mu \mathrm{g} / \mathrm{kg} / 8 \mathrm{~h}$ & $>0.5^{18}$ \\
\hline TDS & TDS & Chronic pain in palliative care & Start: $17.5 \mu \mathrm{g} / \mathrm{h}$ & $3-5^{74}$ \\
\hline (patch containing $5,10,20,30$, or & & & End: $35 \mu \mathrm{g} / \mathrm{h}$ & \\
\hline \multirow[t]{3}{*}{40 mg buprenorphine) } & & & Start: $8.75 \mu \mathrm{g} / \mathrm{h}$ & $2-17^{49}$ \\
\hline & & & End: $35 \mu \mathrm{g} / \mathrm{h}$ & \\
\hline & & & $5-15 \mu g / h$ & $3-10^{82}$ \\
\hline
\end{tabular}

Abbreviations: IV, intravenous; PCA, patient-controlled administration; Cl, continuous infusion; SC, subcutaneous; SL, sublingual; TDS, transdermal delivery system; WGA, week gestational age; max, single maximal dose at the start of continuous infusion. 
Table 3 BPN pharmacological interactions

\begin{tabular}{|c|c|c|}
\hline Drug & Effect & Management \\
\hline \multicolumn{3}{|c|}{ Severe interactions } \\
\hline $\begin{array}{l}\text { Benzondiazepines, } \\
\text { muscle relaxants, } \\
\text { anesthetics, } \\
\text { antipsychotics, } \\
\text { alcohol and } \\
\text { opioids }\end{array}$ & $\begin{array}{l}\text { Increases the risk of BPN overdose, hypotension, respiratory } \\
\text { depression, coma, and death } \\
\text { Alters the usual ceiling effect on respiratory depression induced by BPN } \\
\text { Precipitation of withdrawal symptoms and/or decrease in the analgesic } \\
\text { effect of BPN after combination with mixed agonist opioids or } \\
\text { antagonists }\end{array}$ & $\begin{array}{l}\text { Coadministration of these drugs should be } \\
\text { avoided } \\
\text { Extreme patient vigilance is required if } \\
\text { concomitant use with CNS depressants is } \\
\text { necessary }{ }^{85-88}\end{array}$ \\
\hline Pregabalin & $\begin{array}{l}\text { Increases the risk of BPN overdose, hypotension, respiratory } \\
\text { depression, coma, and death. Alters the usual ceiling effect on } \\
\text { respiratory depression induced by BPN }\end{array}$ & $\begin{array}{l}\text { Coadministration with BPN should be } \\
\text { avoided }^{89}\end{array}$ \\
\hline Escitalopram & Increases the risk of a life-threatening irregular heart rhythm & Caution is advised ${ }^{90}$ \\
\hline \multicolumn{3}{|c|}{ Moderate interactions } \\
\hline Albuterol & $\begin{array}{l}\text { Increases the risk of an irregular heart rhythm, which can be serious and } \\
\text { fatal; however, this is a rare side effect }\end{array}$ & Avoid concomitant use ${ }^{91}$ \\
\hline Duloxetine & Dizziness, drowsiness, confusion, and difficulty in concentrating & Coadministration should be avoided ${ }^{92}$ \\
\hline Fluoxetine & $\begin{array}{l}\text { Dizziness, drowsiness, confusion, and difficulty in concentrating. } \\
\text { Norfluoxetine (active metabolite) inhibits BPN dealkylation }\end{array}$ & $\begin{array}{l}\text { During concomitant use, dosage adjustment } \\
\text { may be necessary }\end{array}$ \\
\hline Quetiapine & $\begin{array}{l}\text { Increases the risk of an irregular heart rhythm, which can be serious and } \\
\text { life threatening, but is rare }\end{array}$ & $\begin{array}{l}\text { Caution and clinical monitoring if concomitant } \\
\text { use is required } 94,95\end{array}$ \\
\hline Laxatives (Senna) & Irregular heartbeat, which can be severe and life threatening, but is rare & Caution in coadministration ${ }^{96}$ \\
\hline
\end{tabular}

Abbreviations: BPN, buprenorphine; CNS, central nervous system.

dizziness, and anorexia (together adding up to 13\%). Other effects such as fatigue, diarrhea, insomnia, respiratory depression, and hallucinations add up to $\leq 5 \% .{ }^{98}$

Transdermal administration causes less adverse reactions than other dosage forms, and there are reports of local erythema (25.4\%), local pruritus (22\%), nausea (11\%-16.7\%), vomiting (3.7\%-9.3\%), dizziness $(6.8 \%)$, fatigue $(5.6 \%)$, constipation $(5.3 \%-7.8 \%)$, sweating (3.7\%), somnolence (4\%), and headache (1.3\%). Swelling and infection at the site of application have been recorded in isolated cases. ${ }^{19,51,75,99,100}$ Most side effects at the patch application site are mild or moderate and generally transient. ${ }^{76}$

Epidural BPN administration considerably increased nausea and vomiting events (80\%) and slightly increased urinary retention $(10 \%)$ during the postoperative period. ${ }^{80}$ Symptoms of mild hypotension were also observed in $1 \%-5 \%$ of patients. ${ }^{22}$

Data regarding respiratory depression in children are rare. Side effects reported in studies comparing BPN and morphine show that nausea/vomiting occurs in $28 \%$ of patients taking BPN versus $16 \%$ taking morphine; and urinary retention occurs in $21 \%$ of patients taking BPN versus $19 \%$ taking morphine. This study did not report the effects on ventilation and BPN was considered safer than morphine in this population. ${ }^{101}$

Respiratory depression induced by BPN can be reversed by administering continuous naloxone infusion $(4 \mathrm{mg} / \mathrm{h}$ for 30 minutes), with minimal possibility of renarcotization. ${ }^{102}$
Other reports suggest that $0.04-0.10 \mathrm{mg} / \mathrm{kg}$ doses of naloxone (maximum $5 \mathrm{mg}$ ) successfully reverse the respiratory depression induced by BPN. ${ }^{19,103-106}$

After the abrupt discontinuation of BPN therapy, patients may experience withdrawal symptoms, which are milder than the symptoms associated with other opioids. The possibility of tolerance after short-term treatment is minimal. ${ }^{19,51}$

No hepatic adverse effects have been reported in individuals receiving BPN at analgesic doses. ${ }^{23}$ In patients with prolonged therapy (1-2 months), effects such as decreases in erythrocytes number, hemoglobin, hematocrit, and total protein concentration have been observed, which reversed after stopping treatment. ${ }^{107}$

\section{Discussion}

The analgesic efficacy of potent opioids such as morphine is well established, and indirect evidence supports opioid use in children and their inclusion in the WHO Model List of Essential Medicines. ${ }^{16}$

Opioids are the basis for the treatment of moderate to severe pain in pediatrics. Although BPN is not the first line of treatment for various pain models, it has been proven to be an effective and safe treatment option for adults.

Due to the vulnerability of the pediatric population and the costs and challenges of conducting clinical studies in children, the current dosage regimen results cannot ensure optimum efficiency and minimal toxicity in these patients. ${ }^{108}$ 
Data provided by the American Association of Poison Control Centers show that cases of accidental ingestion of BPN in children under 6 years have increased from only two in 2002 to 907 cases in $2008 .{ }^{109,110}$ This finding reveals a public health problem and reflects the risk of exposure at home when a family member is using this drug.

A retrospective analysis ( 3 years) of overdoses in children under 6 years (54 cases) showed that the observed effects included drowsiness/lethargy (55\%), vomiting (21\%), miosis (21\%), respiratory depression (7\%), agitation/irritability (5\%), and colonic symptoms (2\%). No deaths were reported. All children required hospitalization, treatment with opioid antagonists, and/or mechanical ventilation. The study concluded that ingestion of $<4 \mathrm{mg}$ of BPN did not cause severe effects and overdoses are generally well tolerated in children. ${ }^{111}$

Compared to adults, BPN in children has a longer clearance related to body weight and a longer duration of action. The risk of inducing respiratory depression when using BPN in combination with other centrally active drugs or opiates is still unknown. ${ }^{33}$

As mentioned earlier, BPN is a drug of clinical interest in pediatrics and it is a choice to consider because of its various formulations and routes of application. BPN also has a prolonged duration of action and metabolism independent of renal function, ${ }^{33}$ which is advantageous in controlling postoperative pain ${ }^{61,80}$ and neuropathic pain. Furthermore, at analgesic doses, BPN has no effect on the immune system, ${ }^{19,112}$ which can be important for cancer pain treatment.

\section{Conclusion}

This meta-analysis makes it clear that there are few studies demonstrating the efficacy and safety of BPN use in children. In recent years, this drug has become widespread in the pediatric population; thus, performing controlled clinical trials in this population for adequate pain control is recommended.

Likewise, conducting pharmacological and biosafety studies to develop evidence-based dosing regimens and thereby minimize the risk of adverse effects is a priority.

\section{Acknowledgments}

We thank Instituto Nacional de Pediatría (INP) and the Pharmacology Laboratory for the federal funding assigned to the project INP-031/2016.

\section{Author contributions}

All authors contributed toward data analysis, drafting and revising the paper and agree to be accountable for all aspects of the work.

\section{Disclosure}

The authors report no conflicts of interest in this work.

\section{References}

1. Loeser JD, Treede RD. The Kyoto protocol of IASP basic pain terminology. Pain. 2008;137(3):473-477.

2. International Association for the Study of Pain. Taxonomy. Available from: https://www.iasp-pain.org/Taxonomy?navItemNumber=576\#P ain. Accessed July 20, 2017.

3. Hartling L, Ali S, Dryden DM, et al. How safe are common analgesics for the treatment of acute pain for children? A systematic review. Pain Res Manag. 2016;2016:5346819.

4. American Academy of Pediatrics, Committee on Psychosocial Aspects of Child and Family Health; Task Force on Pain in Infants, Children, and Adolescents. The assessment and management of acute pain in infants, children, and adolescents. Pediatrics. 2001;108(3):793-797.

5. Goldschneider K, Anand K. Long-term consequences of pain in neonates. In: Schechter N, Berde C, Yaster M, editors. Pain in Infants, Children and Adolescents. New York, NY: Lippincott Williams \& Wilkins; 2003:58-70.

6. Mercadante S. Cancer pain management in children. Palliat Med. 2004;18(7):654-662.

7. Mercadante S, Giarratano A. Pharmacological management of cancer pain in children. Crit Rev Oncol Hematol. 2014;91(1):93-97.

8. Berde C, Solodiuk J. Multidisciplinary programs for management of acute and chronic pain in children. In: Schechter N, Berde C, Yaster M, editors. Pain in Infants, Children and Adolescents. Philadelphia, PA: Lippincott Williams \& Wilkins; 2003:471-486.

9. Carr DB, Goudas LC. Acute pain. Lancet. 1999;353(9169):2051-2058.

10. Chou R, Gordon DB, de Leon-Casasola OA, et al. Management of postoperative pain: a clinical practice guideline from the American Pain Society, the American Society of Regional Anesthesia and Pain Medicine, and the American Society of Anesthesiologists' committee on regional anesthesia, executive committee, and administrative council. J Pain. 2016;17(2):131-157.

11. Groenewald CB, Rabbitts JA, Schroeder DR, Harrison TE. Prevalence of moderate-severe pain in hospitalized children. Paediatr Anaesth. 2012;22(7):661-668.

12. Rabbitts JA, Fisher E, Rosenbloom BN, Palermo TM. Prevalence and predictors of chronic postsurgical pain in children: a systematic review and meta-analysis. J Pain. 2017;18(6):605-614.

13. Chou R, Fanciullo GJ, Fine PG, et al. Clinical guidelines for the use of chronic opioid therapy in chronic noncancer pain. $J$ Pain. 2009;10(2):113-130.

14. Johannes CB, Le TK, Zhou X, Johnston JA, Dworkin RH. The prevalence of chronic pain in United States adults: results of an Internetbased survey. J Pain. 2010;11(11):1230-1239.

15. Maunuksela EL, Korpela R, Olkkola KT. Double-blind, multiple-dose comparison of buprenorphine and morphine in postoperative pain of children. Br J Anaesth. 1988;60(1):48-55.

16. WHO. Guidelines on the pharmacological treatment of persisting pain in children with medical illnesses. Geneva: WHO; 2012. Available from: https://www.ncbi.nlm.nih.gov/books/NBK138354. Accessed May 7, 2017.

17. Zernikow B, Smale H, Michel E, Hasan C, Jorch N, Andler W. Paediatric cancer pain management using the $\mathrm{WHO}$ analgesic ladder - results of a prospective analysis from 2265 treatment days during a quality improvement study. Eur J Pain. 2006;10(7):587-595.

18. Zernikow B, Michel E, Craig F, Anderson BJ. Pediatric palliative care: use of opioids for the management of pain. Paediatr Drugs. 2009;11(2): $129-151$.

19. Davis MP. Buprenorphine in cancer pain. Support Care Cancer. 2005;13(11):878-887.

20. Tigerstedt I, Tammisto T. Double-blind, multiple-dose comparison of buprenorphine and morphine in postoperative pain. Acta Anaesthesiol Scand. 1980;24(6):462-468. 
21. Campbell ND, Lovell AM. The history of the development of buprenorphine as an addiction therapeutic. Ann NYAcad Sci. 2012;1248:124-139.

22. Valderrama JC, Martínez-Raga J, Sancho A. La Buprenorfina [The buprenorphine]. Trastornos Adictivos. 2000;2(2):94-98. Spanish.

23. Johnson RE, Fudala PJ, Payne R. Buprenorphine: considerations for pain management. J Pain Symptom Manage. 2005;29(3):297-326.

24. Likar R. Transdermal buprenorphine in the management of persistent pain - safety aspects. Ther Clin Risk Manag. 2006;2(1):115-125.

25. Chapleo CB, Crossley DI. Terapias de buprenorfina para el tratamiento de la dependencia a opiáceos (Subutex ${ }^{\circledR}$ y Suboxone ${ }^{\circledR}$ ) [Buprenorphine therapies for the treatment of opioid dependence (Subutex ${ }^{\circledR}$ and Suboxone $\left.{ }^{\circledR}\right)$ ]. Trastornos Adictivos. 2003;5(4):320-328. Spanish.

26. Pergolizzi J, Aloisi AM, Dahan A, et al. Current knowledge of buprenorphine and its unique pharmacological profile. Pain Pract 2010;10(5):428-450.

27. Michel E, Anderson BJ, Zernikow B. Buprenorphine TTS for children - a review of the drug's clinical pharmacology. Paediatr Anaesth. 2011;21(3):280-290.

28. Wallenstein SL, Kaiko RF, Rogers AG, Houde RW. Crossover trials in clinical analgesic assays: studies of buprenorphine and morphine. Pharmacotherapy. 1986;6(5):228-235.

29. Micó JA. [Pharmacological profile of the buprenorphine. 5th Congress of the Spain Pain Society]. Salamanca, Spain, October 9th-12th, 2012 Spanish.

30. Plancarte SR, Gutiérrez VH. [Transdermal buprenorphine in patients with oncologic pain]. Cancerología. 2006;1:253-271. Spanish.

31. Cowan A, Lewis JW, Macfarlane IR. Agonist and antagonist properties of buprenorphine, a new antinociceptive agent. Br J Pharmacol. 1977;60(4):537-545.

32. Stein C. The control of pain in peripheral tissue by opioids. $N$ Engl $J$ Med. 1995;332(25):1685-1690.

33. Duggan AW, North RA. Electrophysiology of opioids. Pharmacol Rev. 1983;35(4):219-281.

34. Benedetti C. Neuroanatomy and biochemistry of antinociception. In: Bonica J, Ventafridda V, editors. Advances in Pain Research and Therapy. New York, NY: Raven Press; 1979:31-44.

35. Heel RC, Brogden RN, Speight TM, Avery GS. Buprenorphine: a review of its pharmacological properties and therapeutic efficacy. Drugs. 1979;17(2):81-110.

36. Picard N, Cresteil T, Djebli N, Marquet P. In vitro metabolism study of buprenorphine: evidence for new metabolic pathways. Drug Metab Dispos. 2005;33(5):689-695.

37. Rouguieg K, Picard N, Sauvage FL, Gaulier JM, Marquet P. Contribution of the different UDP-glucuronosyltransferase (UGT) isoforms to buprenorphine and norbuprenorphine metabolism and relationship with the main UGT polymorphisms in a bank of human liver microsomes. Drug Metab Dispos. 2010;38(1):40-45.

38. Vadivelu N, Anwar M. Buprenorphine in postoperative pain management. Anesthesiol Clin. 2010;28(4):601-609.

39. Hand CW, Sear JW, Uppington J, Ball MJ, McQuay HJ, Moore RA. Buprenorphine disposition in patients with renal impairment: single and continuous dosing, with special reference to metabolites. $\mathrm{Br} J$ Anaesth. 1990;64(3):276-282.

40. Pergolizzi J, Boger RH, Budd K, et al. Opioids and the management of chronic severe pain in the elderly: consensus statement of an International Expert Panel with focus on the six clinically most often used World Health Organization Step III opioids (buprenorphine, fentanyl, hydromorphone, methadone, morphine, oxycodone). Pain Pract. 2008;8(4):287-313.

41. Khanna IK, Pillarisetti S. Buprenorphine - an attractive opioid with underutilized potential in treatment of chronic pain. J Pain Res. 2015;8:859-870.

42. Lavonas EJ, Banner W, Bradt P, et al. Root causes, clinical effects, and outcomes of unintentional exposures to buprenorphine by young children. J Pediatr. 2013;163(5):1377-1383.

43. Brown SM, Holtzman M, Kim T, Kharasch ED. Buprenorphine metabolites, buprenorphine-3-glucuronide and norbuprenorphine3-glucuronide, are biologically active. Anesthesiology. 2011;115(6): $1251-1260$
44. Michel E, Zernikow B. [Buprenorphine use in children. A clinical pharmacological overview]. Monstsschr Kinderheilkd. 2006;154:799-807. German.

45. Bullingham RE, McQuay HJ, Moore A, Bennett MR. Buprenorphine kinetics. Clin Pharmacol Ther. 1980;28(5):667-672.

46. Chawarski MC, Moody DE, Pakes J, O'Connor PG, Schottenfeld RS. Buprenorphine tablet versus liquid: a clinical trial comparing plasma levels, efficacy, and symptoms. J Subst Abuse Treat. 2005;29(4):307-312.

47. Mendelson J, Upton RA, Everhart ET, Jacob P 3rd, Jones RT. Bioavailability of sublingual buprenorphine. J Clin Pharmacol. 1997;37(1):31-37.

48. Nath RP, Upton RA, Everhart ET, et al. Buprenorphine pharmacokinetics: relative bioavailability of sublingual tablet and liquid formulations. J Clin Pharmacol. 1999;39(6):619-623.

49. Ruggiero A, Coccia P, Arena R, et al. Efficacy and safety of transdermal buprenorphine in the management of children with cancer-related pain. Pediatr Blood Cancer. 2013;60(3):433-437.

50. Terlinden R, Stadler T. Pharmacokinetic study on single application of buprenorphine transdermal system (TDS). In: Proceedings of the Third EFIC Congress "Pain in Europe III, 2000: Advances in Pain Research and Therapy;" Nice, France: September 26-29th, 2000.

51. Evans HC, Easthope SE. Transdermal buprenorphine. Drugs. 2003;63(19):1999-2010.

52. Filitz J, Griessinger N, Sittl R, Likar R, Schuttler J, Koppert W. Effects of intermittent hemodialysis on buprenorphine and norbuprenorphine plasma concentrations in chronic pain patients treated with transdermal buprenorphine. Eur J Pain. 2006;10(8):743-748.

53. Likar R, Kayser H, Sittl R. Long-term management of chronic pain with transdermal buprenorphine: a multicenter, open-label, followup study in patients from three short-term clinical trials. Clin Ther 2006;28(6):943-952.

54. Olkkola KT, Maunuksela EL, Korpela R. Pharmacokinetics of intravenous buprenorphine in children. Br J Clin Pharmacol. 1989;28(2):202-204.

55. Barrett DA, Simpson J, Rutter N, Kurihara-Bergstrom T, Shaw PN, Davis SS. The pharmacokinetics and physiological effects of buprenorphine infusion in premature neonates. Br J Clin Pharmacol. 1993;36(3):215-219.

56. Bloms-Funke P, Gillen C, Schuettler AJ, Wnendt S. Agonistic effects of the opioid buprenorphine on the nociceptin/OFQ receptor. Peptides. 2000;21(7):1141-1146.

57. Leander JD. Buprenorphine has potent kappa opioid receptor antagonist activity. Neuropharmacology. 1987;26(9):1445-1447.

58. Leander JD. Buprenorphine is a potent kappa-opioid receptor antagonist in pigeons and mice. Eur J Pharmacol. 1988;151(3):457-461.

59. Negus SS, Bidlack JM, Mello NK, Furness MS, Rice KC, Brandt MR. Delta opioid antagonist effects of buprenorphine in rhesus monkeys. Behav Pharmacol. 2002;13(7):557-570.

60. Pick CG, Peter Y, Schreiber S, Weizman R. Pharmacological characterization of buprenorphine, a mixed agonist-antagonist with $\mathrm{K} 3$ analgesia. Brain Res. 1997;744(1):41-46.

61. Pergolizzi J Jr, Taylor R Jr, Plancarte R, Bashkansky D, Muniz E. [Buprenorphine is a good option for post-operative pain management?] Revista de la Sociedad Española del Dolor. 2012; 19(6):281-292. Spanish.

62. Recker MD, Higgins GA. The opioid receptor like-1 receptor agonist Ro 64-6198 (1S,3aS-8-2,3,3a,4,5,6-hexahydro-1H-phenalen-1-yl-1phenyl-1,3,8-triaza-spiro[4.5 ]decan-4-one) produces a discriminative stimulus in rats distinct from that of a mu, kappa, and delta opioid receptor agonist cue. J Pharmacol Exp Ther. 2004;311(2):652-658.

63. Greenwald MK, Johanson CE, Moody DE, et al. Effects of buprenorphine maintenance dose on mu-opioid receptor availability, plasma concentrations, and antagonist blockade in heroin-dependent volunteers. Neuropsychopharmacology. 2003;28(11):2000-2009.

64. Hou Y, Tan Y, Belcheva MM, Clark AL, Zahm DS, Coscia CJ. Differential effects of gestational buprenorphine, naloxone, and methadone on mesolimbic mu opioid and ORL1 receptor G protein coupling. Brain Res Dev Brain Res. 2004;151(1-2):149-157. 
65. Lutfy K, Eitan S, Bryant CD, et al. Buprenorphine-induced antinociception is mediated by mu-opioid receptors and compromised by concomitant activation of opioid receptor-like receptors. J Neurosci. 2003;23(32):10331-10337.

66. Hovell BC. Comparison of buprenorphine, pethidine and pentazocine for the relief of pain after operation. Br JAnaesth. 1977;49(9):913-916.

67. Banks CD. Overdosage of buprenorphine: case report. $N Z$ Med J. 1979;89(633):255-257.

68. Kamel MM, Geddes IC. A comparison of buprenorphine and pethidine for immediate postoperative pain relief by the i.v. route. Br JAnaesth. 1978;50(6):599-603.

69. Dahan A, Teppema LJ. Influence of anaesthesia and analgesia on the control of breathing. Br J Anaesth. 2003;91(1):40-49.

70. Dahan A, Yassen A, Bijl H, et al. Comparison of the respiratory effects of intravenous buprenorphine and fentanyl in humans and rats. $\mathrm{Br} J$ Anaesth. 2005;94(6):825-834.

71. Dahan A, Yassen A, Romberg R, et al. Buprenorphine induces ceiling in respiratory depression but not in analgesia. Br J Anaesth. 2006;96(5):627-632.

72. Hambrook JM, Rance MJ. The interaction of buprenorphine with the opiate receptor: lipophilicity as a determining factor in drug-receptor kinetics. In: Kosterlitz HW, editor. Opiates and Endogenous Opioid Peptides. Amsterdam: Elsevier/North Holland Biomedical Press; 1976:295-301.

73. Drugs.com. Butrans patch. Available from: http://www.drugs.com/ pro/butrans-patch.html. Accessed July 20, 2017.

74. Attinà $\mathrm{G}$, Ruggiero A, Maurizi $\mathrm{P}$, Arlotta A, Chiaretti A, Riccardi R. Transdermal buprenorphine in children with cancer-related pain. Pediatr Blood Cancer. 2009;52(1):125-127.

75. Böhme K. Buprenorphine in a transdermal therapeutic system - a new option. Clin Rheumatol. 2002;21(Suppl 1):S13-S16.

76. Kress HG. Clinical update on the pharmacology, efficacy and safety of transdermal buprenorphine. Eur J Pain. 2009;13(3):219-230.

77. Harcus AW, Ward AE, Smith DW. The monitored release of buprenorphine: results in the young. J Int Med Res. 1980;8(2):153-155.

78. Girotra S, Kumar S, Rajendran KM. Postoperative analgesia in children who have genito-urinary surgery. A comparison between caudal buprenorphine and bupivacaine. Anaesthesia. 1990;45(5):406-408.

79. Anilkumar TK, Karpurkar SA, Shinde VS. Post-operative pain relief in children following caudal bupivacaine and buprenorphine-a comparative study. J Postgrad Med. 1994;40(2):61-64.

80. Khan FA, Memon GA, Kamal RS. Effect of route of buprenorphine on recovery and postoperative analgesic requirement in paediatric patients. Paediatr Anaesth. 2002;12(9):786-790.

81. Bravo-Matus CA, Flores-Zuñiga RM. Sublingual buprenorphine in pediatric surgery. Cir Cir. 1997;65(1):6-9. Spanish.

82. Prapaitrakool S, Hollmann MW, Wartenberg HC, Preckel B, Brugger $\mathrm{S}$. Use of buprenorphine in children with chronic pseudoobstruction syndrome. Clin J Pain. 2012;28(8):722-725.

83. Keller GA, Ponte ML, Di Girolamo G. Other drugs acting on nervous system associated with QT-interval prolongation. Curr Drug Saf. 2010;5(1):105-111.

84. Kao DP, Haigney MC, Mehler PS, Krantz MJ. Arrhythmia associated with buprenorphine and methadone reported to the Food and Drug Administration. Addiction. 2015;110(9):1468-1475.

85. Martin HA. The possible consequences of combining lorazepam and buprenorphine/naloxone: a case review. J Emerg Nurs. 2011;37(2): 200-202.

86. Hakkinen M, Launiainen T, Vuori E, Ojanpera I. Benzodiazepines and alcohol are associated with cases of fatal buprenorphine poisoning. Eur J Clin Pharmacol. 2012;68(3):301-309.

87. Schuman-Olivier Z, Hoeppner BB, Weiss RD, Borodovsky J, Shaffer HJ, Albanese MJ. Benzodiazepine use during buprenorphine treatment for opioid dependence: clinical and safety outcomes. Drug Alcohol Depend. 2013;132(3):580-586.
88. US Food and Drug Administration. FDA warns about serious risks and death when combining opioid pain or cough medicines with benzodiazepines; requires its strongest warning. Available from: http://www. fda.gov/downloads/Drugs/DrugSafety/UCM518672.pdf. Accessed August 31, 2016.

89. Substance Abuse and Mental Health Services Administration. Clinical Guidelines for the Use of Buprenorphine in the Treatment of Opioid Addiction. Rockville, MD: Substance Abuse and Mental Health Services Administration; 2004.

90. Health Canada. Antidepressant Cipralex (escitalopram): updated information regarding dose-related heart risk. Available from: http://www. healthycanadians.gc.ca/recall-alert-rappel-avis/hc-sc/2012/13674aeng.php. Accessed August 29, 2017.

91. Ferguson GT, Funck-Brentano C, FischerT, Darken P, Reisner C. Cardiovascular safety of salmeterol in COPD. Chest. 2003;123(6):1817-1824.

92. Plushner SL. Valerian: Valeriana officinalis. Am J Health Syst Pharm. 2000;57(4):328-335.

93. Lemberger L, Rowe H, Bosomworth JC, Tenbarge JB, Bergstrom RF. The effect of fluoxetine on the pharmacokinetics and psychomotor responses of diazepam. Clin Pharmacol Ther. 1988;43(4):412-419.

94. Vieweg WV. New generation antipsychotic drugs and QTc interval prolongation. Prim Care Companion J Clin Psychiatry. 2003;5(5):205-215.

95. Sala M, Vicentini A, Brambilla P, et al. QT interval prolongation related to psychoactive drug treatment: a comparison of monotherapy versus polytherapy. Ann Gen Psychiatry. 2005;4(1):1.

96. Muller-Lissner SA. Adverse effects of laxatives: fact and fiction. Pharmacology. 1993;47(Suppl 1):138-145.

97. Kalso E, Edwards JE, Moore RA, McQuay HJ. Opioids in chronic non-cancer pain: systematic review of efficacy and safety. Pain. 2004;112(3):372-380.

98. Wiffen PJ, Derry S, Moore RA. Impact of morphine, fentanyl, oxycodone or codeine on patient consciousness, appetite and thirst when used to treat cancer pain. Cochrane Database Syst Rev. 2014;5:CD011056.

99. Griessinger N, Sittl R, Likar R. Transdermal buprenorphine in clinical practice - a post-marketing surveillance study in 13,179 patients. Curr Med Res Opin. 2005;21(8):1147-1156.

100. Muriel C, Failde I, Micó JA, Neira M, Sanchez-Magro I. Effectiveness and tolerability of the buprenorphine transdermal system in patients with moderate to severe chronic pain: a multicenter, open-label, uncontrolled, prospective, observational clinical study. Clin Ther. 2005;27(4):451-462.

101. Maunuksela EL, Korpela R, Olkkola KT. Comparison of buprenorphine with morphine in the treatment of postoperative pain in children. Anesth Analg. 1988;67(3):233-239.

102. Dahan A, Aarts L, Smith TW. Incidence, reversal, and prevention of opioidinduced respiratory depression. Anesthesiology. 2010;112(1):226-238.

103. Pedapati EV, Bateman ST. Toddlers requiring pediatric intensive care unit admission following at-home exposure to buprenorphine/naloxone. Pediatr Crit Care Med. 2011;12(2):e102-e107.

104. Cho CS, Calello DP, Osterhoudt KC. Exploratory buprenorphine ingestion in an infant. Ann Emerg Med. 2006;48(1):109.

105. Geib AJ, Babu K, Ewald MB, Boyer EW. Adverse effects in children after unintentional buprenorphine exposure. Pediatrics. 2006;118(4):1746-1751.

106. Jitpakdee T, Mandee S. Strategies for preventing side effects of systemic opioid in postoperative pediatric patients. Paediatr Anaesth. 2014;24(6):561-568.

107. Scott DH, Arthur GR, Scott DB. Haemodynamic changes following buprenorphine and morphine. Anaesthesia. 1980;35(10):957-961.

108. Krekels EHJ, van Hasselt JGC, van den Anker JN, Allegaert K, Tibboel D, Knibbe CAJ. Evidence-based drug treatment for special patient populations through model-based approaches. Eur J Pharm Sci. 2017;109S:S22-S26. 
109. Boyer EW, McCance-Katz EF, Marcus S. Methadone and buprenorphine toxicity in children. Am J Addict. 2010;19(1):89-95.

110. Bronstein AC, Spyker DA, Cantilena LR Jr, Green JL, Rumack BH, Dart RC. 2010 Annual report of the American Association of Poison Control Centers' national poison data system (NPDS): 28th annual report. Clin Toxicol (Phila). 2011;49(10):910-941.
111. Hayes BD, Klein-Schwartz W, Doyon S. Toxicity of buprenorphine overdoses in children. Pediatrics. 2008;121(4): e782-e786.

112. Gomez-Flores R, Weber RJ. Differential effects of buprenorphine and morphine on immune and neuroendocrine functions following acute administration in the rat mesencephalon periaqueductal gray. Immunopharmacology. 2000;48(2):145-156.

\section{Publish your work in this journal}

The Journal of Pain Research is an international, peer reviewed, open access, online journal that welcomes laboratory and clinical findings in the fields of pain research and the prevention and management of pain. Original research, reviews, symposium reports, hypothesis formation and commentaries are all considered for publication

\section{Dovepress}

The manuscript management system is completely online and includes a very quick and fair peer-review system, which is all easy to use. Visit http://www.dovepress.com/testimonials.php to read real quotes from published authors. 